\title{
Review of "The Gambler" and F.M. Dostoevsky in the light of addiction inclination
}

\author{
Jasminka Matić ${ }^{1}$ \\ ${ }^{1}$ Neuropsichiatric Hospital "Dr. Ivan Barbot", Popovača, Croatia \\ “..Dostoevsky is a spiritual author... The son of a doctor who was killed by his own \\ peasants because of cruelty and humiliation... His mother died in childhood. A \\ writer who nurtures a tradition of idealism and humanity whose boundaries he \\ has questioned all his life. Christian mystic, idealist and rebel, anarchist. Utopian \\ socialist. "Whence so much "subversive ideological energy that no regime could have \\ channeled, let alone an obscure Russian despotism" [1].
}

\begin{abstract}
Dostoevsky's spirit is broken by a difficult childhood, years of imprisonment and forced military service in the difficult conditions of remote Russia, and the shackles of married life with the "sick, hysterical widow". Wandering through dreamy Europe made him aware of the attachment to the Russian homeland and revealed love and allusion of peace; he falls in love with Ana by dictating the text of the "Gambler", which will provide them with bread and shelter in the days of losing the gambling luck and questionable existence. In his wandering through Europe as the "land of holy wonders", Dostoevsky informs us through the confessions of the gambler Alexei about the temptations of the "world" addicted to the gambling table. The significance of divisive passions is questioned: those towards women, love and even more, gambling, destructive, demonic. In 27 days while he was presenting Ana with the thoughts of the main character of the "Gambler", and she was recording them in a transcript, the writer was going through his own agony. The novel will see the light of day, but unlike Alexei, a character waiting for a new tomorrow to decide on ending a life driven by an unhealthy addictive habit, Dostoevsky, after the novel ends, experiences catharsis and sails into economic security by taking royalties for this and subsequent novels. As when after a stormy night at sea, a sunny morning dawns, a hint of love, happiness and the desired family peace is prayed to the author. Ana will focus the writer, a gambler, on family life and caring for children, and abduct him from addiction by sailing with him to the next "storm". The basic theme of the novel - the obsession with gambling - is the experience of Dostoevsky, a writer with "a heart in which God and Satan fight, and the pledge is human life." In the days when in the hustle and bustle of modern life, COVID-19, complete human alienation and escalation of violence we turn to the spiritual, looking for a way out in the metaphysical, surreal, healing and nurturing, and rational and explainable does not offer a final answer, someone seeks a way out of addiction and someone in a classic, something familiar and valuable. Or in metaphysics that goes beyond the physical and the knowable, in an attempt to reach the higher, the spiritual. The return to the great connoisseur of the human psyche, Dostoevsky, in a return to the interest in man, the inspiration of the human and the humane, but also the space behind knowable and the "metaphysical drama". The idea of the French writer Albarez that for Dostoevsky, "in contrast to most other novelists, man is primarily not a biological, social, economic, psychological, but a metaphysical being", becomes understandable.
\end{abstract}

Key words: Europe; temptations; hell of passion and demons; addiction; gambling; love; metaphysics

Copyright @ 2021 KBCSM, Zagreb

e-mail: apr.kbcsm@gmail.com•www.http://apr.kbcsm.hr

\section{Correspondence to:}

Jasminka Matić, clinical psychologist, mr. spec.

Neuropsychiatric Hospital "Dr. Ivan Barbot", Jelengradska 1, Popovača, Croatia

Phone: +385 44569341

E-mail: jasminka.matic@bolnicapopovaca.hr
"I was in a frensy and threw that whole pile of money on the red - and suddenly I was shocked!

Only that one time during that whole evening, during the whole game, fear permeated me with cold, and 
responded with trembling in arms and legs. I felt with borror, and in an instant, I realized: what would losing mean to me then! My entire life has been at stake!" [2]

\section{Introduction}

"Then I remember, I invested two thousand florins again in twelve middle ones, and I lost; I invested my gold and eighty friedrichdors, and I lost. I was overwhelmed with rage, I grabbed the last two thousand florins I had left and distributed them to the first twelve - just in case, carelessly, without a bill! After all, there was a moment of anticipation, perhaps similar to the impression Madame Blanchard had experienced when she fell to the ground from a bot air balloon" [2].

As stated by the eminent authors in the field of addiction, being addicted to gambling "can be defined as investing money or something that has material value in an event of uncertain outcome with the purpose of increasing the invested amount or goods, or as investing financial values in events of uncertain outcomes with the intention of earning. Without a value role, gambling turns into a game or fun" [3].

„Being addicted to gambling means always gambling more than intended, repeatedly unsuccessfully trying to quit, neglecting obligations due to gambling and failing at one of the most important levels of life, gambling for ever- increasing amounts with less and less pleasure..., feeling nervous, depressed, miserable, if not gambling, to feel remorse, after gambling, then gamble again to drive away that feeling.." [4].

"I piled up all of my gold and put it in my pockets; I grabbed all the bills and immediately moved to another table, to another hall, where there was another roulette; a whole crowd rushed after me; there they cleared a place for me, and I began to invest again at random without counting. I just don't know what saved me"!
..I must have been very distracted; I remember the croupier correcting me a few times in the game. I made big mistakes. My temples were wet with sweat and my hand were shaking..." [2].

Alexei is a gambler who feels equally "homely" at the gambling tables of Roulletenburg, Baden and Homburg. Upon his return from Paris, he analyzes his feelings for Polina, aware that he occasionally "longs for her like crazy, becomes completely out of his mind, and even sees her in front of him in a dream."

"And then I asked myself the question again: do I love her? And once gain I could not answer him, that is, rather, again, for the hundredth time, I answered myself that I hated her." [2].

He is torn by ambivalence and the struggle of opposing instincts. At the moment.

"At the moment, thoughts come to me to strangle ber", "if he could lightly stab her in the chest, it seems to me that he would attack him with pleasure"... "her awareness of being inaccessible to me gives her extraordinary pleasure".. "she looks at me like an ancient empress who began to undress in front of a slave without considering him a man"... [2].

At her urging, he obediently goes to win the roulette for her at all costs. From the passion for a woman and the strong struggle to resist the urge, Alexei burns out, and as if nothing is stronger... Or still...Confirms that the power of passion for gambling is stronger... Alexei's description of the casino is in the manner of a blazed experienced gambler:

"There is no splendor in these disgusting halls, and bold is not only not found in piles on the tables, but hardly at all. Of course, sometimes during the season, a peculiarperson appears, and Englishman or some Asian, a Turk, like this summer, and suddenly loses or gains a lot; others, on the other hand, play for small sums and there is generally very little money on the table." [2]. 
Forms of addiction include: “...social gambling that is used solely for leisure and entertainment in leisure time, with a symbolic stake and limited loss or gain; serious social gambling in which gamblers find a basic form of entertainment in gambling and spend all their free time gambling. They adhere to predetermined possible losses"; problematic gambling that occupies most of the free time, with an uncontrolled bet, the inability to limit winnings or losses, and a compulsive desire to regain a lost bet" [4].

"We invested, we lost; then again, and we lose again...

- Grandma, all twenty thousand are gone" I told her.

- "I see that they are gone", she said in a kind of furious serenity, so to speak, if that is even possible to say.

-I see my child, I see" she murmured, looking in front of her motionless and as if rethinking. Eh, even if she died, put another four thousand guilders!

-But there is no money, Grandma; here in the wallet are our five percent bonds and some more papers, but there is no money.

- And in the coin purse?

-Only small change, Grandma.

-And are there exchange offices here? They told

me that our papers could be exchanged, Grandma asked firmly

- As many as you want! However, you are going to lose in that exchange, that is...

-Nonsense! I will get it back!! Drive me! Call those bastards!” [2].

One of the criteria for gambling includes the phenomenon that "After losing money on gambling, he often returns the next day to recoup/chase his own debts" [5].

Grandma and Alexei's gambling passion contains a number of criteria for a more severe form of gambling addiction: the need to achieve the desired excitement; over unrest when unsuccessfully trying to reduce or stop gambling; preoccupation with how to repair the damage; with periods of feeling unwell, returning to make up for lost, diminishing the significance of the damage; by losing other important opportunities because of it and desperate attempts to alleviate the financial situation caused by gambling [5].

Lost in gambling and ecstasy, the other one of the characters in the novel - General - forgets about his minor children" who were completely abandoned and robed by this crazy man" [2]. At one point, Alexei gains insight into his own condition:

"I was also a gambler. I felt it right at this moment. My hands and legs were shaking, blood rushed to my head" [2].

The ambiance of fashionable casinos has long since replaced cave dwellings considered to be the first places of gambling. From the mentions in the Old and New Testaments, it is known that the ancient people knew gambling. "The modern form of roulette was perfected by the French brothers Francois and Louis Blanc..." [4].

When describing the Frenchman, Dostoevsky pays attention by recognizing the disparagement in saying that "Russians are not even capable of gambling". Alexei considers the difference between the French and the Russians, finding that Russian ladies are attracted to the Frenchmen because the form is important to them. He considers himself to have neither form nor dignity because he has lost his head for Polina and feels like her slave. Entourage of Roulettenburg leaves the impression of a lazy, carefree, frivolous society, eager to live well at someone else's expense.

According to Roberts the gambling fits into a personal worldview, lifestyle, and corresponding social group [4]. "..everything seemed so dirty-somehow morally disgusting and dirty. By no means am I talking about those lustful and anxious 
faces that surround the gambling tables in dozens or even hundreds" [2].

Goffman emphasizes that gambling is motivated by a desire to leave the desired impression on others, showing skill, composure in gaming, regardless of gain or loss [4]. The main character of the Gambler, "Alexei", through whom Dostoevsky himself speaks, would agree with him. Alexei states that "he divides gambling into a gentleman's game when a thousand francs can be invested if the gentleman is rich, but only in fact, for the sake of the game, solely for fun, only to watch the process of gain and loss, but he must never be interested in gain, and other, plebeian, selfish, games of all kinds of scum" [2].

Alexei's self-description from the period speaks in favor of his propensity for multiple addictions planning in Paris with the calculated Madame Blanche with whom he leaves Rouletteburg after a great gambling win, losing hope that Polina cares for him:

'I started resorting to champagne very often because I was bothered by sadness and the greatest boredom all the time...[1]. He goes through ups and downs by bimself, and informs the reader about it: I expect, I calculate, I jog all day by the gambling table and I watch the game, I even see the game in my dreams, but in all this, it seems to me that I am numb, as if I am stuck in some mud." [2].

What biological and socio-psychological factors prevail and determine the fate of gamblers?

This time I am asking a question to you, the readers, as Dostoevsky directed it through Alexei's word much earlier. Didn't Dostoevsky himself, no less than his main character, long for excitement and an extra dose of adrenaline? Russian winters are long and severe, especially those in the Siberian north where he spent years in prison.

The association of gambling urge with depression is often in psychoanalytic interpretations of this addiction. It suppresses the guilt that some will find in the writer's interpreta- tions of the potential guilt associated with the violent death of an authoritarian father (killed by a family coachman), which, they find, may have been prevented. In this context, Freud's "consideration of the gambler's masochistic position in conflict with his father's authority), is worth mentioning, as well as data on the unhappy childhood of most of them (either rejected or lonely) and destructive relationships with cruel, cold perfectionist fathers [4]. The gambling position is a choice of a life without responsibility and with dominant immature defenses; immature, manipulative, invested in gambling addiction, emotionally engaged with bright eyes of excitement just as the roulette wheel, card, and waiting for the result on the gambling table. In the mistaken belief that they can influence the outcome, they lose years, and the biggest stake; own life!

In the period of devastating effects of gambling addiction and wandering in Europe, Dostoevsky was lucky that Ana's love rescued him from the hell of addiction and the existential vacuum. Alexei did not recognize that chance, Polina's love remained unrecognized in the heat of the gambling game. At the end of the novel, he sighs with memories of Roulettenburg with sadness:

"then I gambled everything, everything...Coming out of the station building, I look in my vest pocket and feel another guilder moving. Ha, so I'll have something for lunch!" I thought, but after taking a bundred steps, I returned. I put that guilder in manque (this time it was on manque) and really, there is something special about feeling when you are alone, in someone else's world, far from home, away from friends and when you don't now what to eat that day, you invest your last guilder, absolutely the last one!.. And what if I had lost my spirit then, if I hadn't had the courage to decide?

I got it, and after twenty minutes, I came out with one hundred and seventy guilders in my pocket...

Tomorrow, tomorrow it will all end! 


\section{Acknowledgements}

None.

\section{Conflict of Interest}

None to declare.

\section{References}

1. Wikipedia. Dostojevski FM [Internet]. 2020 [cited 2020 Sep 20]. Available from: https://bs.wikipedia.org/wiki/ Fjodor_Dostojevski

2. Dostojevski FM. Kockar „Izabrana djela Fjodora Mihajloviča Dostojevskog". Beograd: Izdavačka radna organizacija „Rad”; 1986.

3. Torre R, Zoričić Z. Kockanje i klađenje-od zabave do ovisnosti. Zagreb: HSKLA; 2013.

4. Zoričić Z. Ovisnosti; prevencija, liječenje, oporavak. Zagreb: Školska knjiga; 2018.
5. Američka Psihijatrijska Udruga. DSM-5, Dijagnostički i statistički priručnik za duševne poremećaje. Jukić V, Arbanas G, ur. hrv. izdanja. Naklada Slap: Jastrebarsko; 2013.

6. Studentski.hr. Intrigantne zanimljivosti o Dostojevskom, književniku koji se vratio iz „kuće mrtvih“ [Internet]. 2020 [cited 2020 Sep 20]. Available from: https:// studentski.hr/vijesti/na-danasnji-dan/intrigantne-zanimljivosti-o-dostojevskom-knjizevniku-koji-se-vratioiz-kuce-mrtvih

\section{Osvrt na "Kockara" i F.M. Dostojevskog u svjetlu sklonosti ovisnosti}

Sažetak- U danima kada se u užurbanosti suvremenog života, žrtava COVIDA 19, posvemašnje ljudske otuđenosti i eskalacije nasilja, okrećemo duhovnom tražeći izlaz u metafizičkom, nadrealnom, ljekovitom i njegujućem, a racionalno i objašnjivo ne nudi konačni odgovor, netko izlaz traži u sredstvu ovisnosti, a netko u klasici, nečem poznatom i vrijednom. Ili metafizici koja ide dalje od fizičkog i spoznatljivog, u pokušaju dosizanja višeg, spiritualnog. Povratak velikom poznavaocu ljudske psihe, Dostojevskom, povratak je interesu za čovjeka, inspiraciji ljudskim i humanim, ali i prostoru iza spoznatljivog i "metafizičkoj drami”. U skitnjama Europom, Dostojevski nas, kroz ispovijest kockara Alekseja izvještava o iskušenjima "svite" ovisne o kockarskom stolu. Propituje se značaj razdorne strasti: i one prema ženi, ljubavne, a još više, kockarske, rušilačke, demonske. Misao francuskog pisca Albaresa da je za Dostojevskog, "u opreci prema većini ostalih romanopisaca, čovjek primarno ne biološko, socijalno, ekonomsko, psihološko, nego metafizičko biće" [6], postaje razumljivom.

Ključne riječi: Europa; iskušenja; pakao strasti i demona; ovisnosti; kocka; ljubav; metafizika

* Sa 2021. godinom se navršava 200 godina od rodenja velikog pisca (rođen 11.11.1821) u Moskvi. Umire u 60.oj godini nakon duge i teške bolesti, od posljedica krvarenja izazvanoga epileptičnim napadom. "Prema izvjestajima policije, na posljednji mu je ispraćaj došlo 100000 ljudi, mahom studenata, a pogreb se na kraju pretvorio u demonstracije protiv carskog sustava” [6].

*The year 2021 marks the 200th anniversary of the birth of the great writer (born on November 11, 1821) in Moscow. He dies at the age of 60 after a long and severe illness, from the consequences of bleeding caused by an epileptic seizure. "According to police reports, 100,000 people, mostly students, came to his last farewell, and the funeral eventually turned into demonstrations against the imperial system" [6]. 
